\title{
The implications of Jesus' radical love
}

\section{Book Title:}

Jesus se radikale liefde verander ons wêreld: 'The politics of Jesus' in Afrikaans

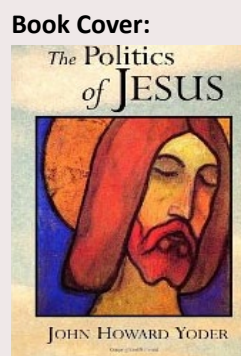

Editors:

John H. Yoder (transl. Andries Cilliers)

ISBN:

[not available]

\section{Publisher:}

Lux Verbi BM, Wellington, 2007 , p. 352, cost unknown

Review Title:

The implications of Jesus' radical love

\section{Reviewer:}

Hennie J.C. Pieterse

(Emeritus Professor)

\section{Affiliation:}

${ }^{1}$ Department of Practical Theology, University of Pretoria, South Africa

\section{Email:}

pietehjc@absa.co.za

Postal address:

Department of Practical

Theology, Faculty of

Theology, University of

Pretoria, Pretoria 0002,

South Africa

\section{How to cite this book}

review:

Pieterse, H.J.C., 2011, 'The

implications of Jesus' radical

love', HTS Teologiese Studies/

Theological Studies 67(3),

Art. \#1139, 1 page. http://

dx.doi.org/10.4102/hts.

v67i3.1139

C) 2011. The Authors.

Licensee: AOSIS

OpenJournals. This work

is licensed under the

Creative Commons

Attribution License.
Andries van Aarde wrote about the historical Jesus and his social identity as a fatherless person, calling God 'father' (paper read by A.G. van Aarde at the University of Pretoria, 'Public-theological debate - Who was the real Jesus?', 16 October 2008, pp. 12-13):

brought healing for marginalised people in terms of his message about God, acting as father-king in his divine empire ... over against the patriarchal conventions of the powers that were in Jerusalem, Sepphoris/ Tiberias and Rome. Jesus died because of the 'subversiveness' of this 'ethos of compassion ...

This book by Yoder addresses the very implications of Jesus' radical love. Although the author uses New Testament scholarly results of not later than 1972, it is still worthwhile to read this excellent book on Yoder's interpretation of the historical message of Jesus and the implications for an ethical and political understanding of this message. Jesus' kingdom message should not be interpreted as a spiritual kingdom. Jesus made a political choice against the powers of his times. It is an alternative way of life, of non-violent resistance through radical love to the usual (often unjust) political rule, but it is an outspoken political choice. Chapters on the possibility of a messianic ethics, the coming of the kingdom, the option of non-violent resistance, the fact that the disciples of Jesus followed him to the end, and Christ and power, carry a richness of insights for our own situation.

This book makes sense for us today in our own struggle for a peaceful, non-violent and just society in South Africa. It is a great challenge to the churches and to Christians in our situation to start living and witnessing in the spirit of Jesus' kingdom message in our efforts to, inter alia, bring about economic justice. 